INTERNATIONAL HIGHER EDUCATION Number 74 Winter 2014

Pages 16-17

\title{
Franchising, Validation, and Branch Campuses in the European \\ Union
}

\author{
LUKAS BISCHOF
}

Lukas Bischof is a project manager with CHE Consult, a German consultancy and research company on higher education, based in Berlin. E-mail: lukas.bischof@che-consult.de.

The Bologna process aims at creating a European higher education area with more comparable, compatible, and coherent higher education systems in Europe. Indeed, students, staff, and research teams are increasingly mobile within that area. In addition, a growing number of institutions are offering their study programs across borders. The most common form of such cross-border provision of higher education (CBHE) are joint or double degrees. Branch campuses, franchising or validation arrangements are less frequent but have lately stirred controversy in European higher education.

\section{European Legislation Has Created a Common Market}

The European common market guarantees that European citizens have their qualifications recognized in any EU member state in the same way they would be recognized in their own country. At the same time, it allows any European business to offer their services in any other EU member state. A holder of a Spanish diploma is therefore allowed to work in their profession in Germany or any 
other EU country, and a company from Poland is allowed to offer its services in Ireland. No member state is allowed to infringe on these rights.

Education on the other hand has always been the exclusive domain of each EU member state. In 2008, however, in a series of recent landmark rulings, the Court of Justice of the European Union has established that franchised or validated study programs fall within the responsibilities of the member state in which the diploma-granting institution is established, irrespective of where the course took place. This ruling now effectively allows a British university to allow a nonaccredited institution (or company) based in another EU country (e.g., Greece) the right to issue British degrees, in spite of the receiving country's exclusive responsibility for education. The receiving country must therefore accept these degrees as any other EU degree. Quality assurance of such degrees is the sole responsibility of the exporting country, although to many observers it is not clear how or whether franchised or validated degrees are quality assured by their degree-granting institutions.

\section{The European Mapping OF Cross-Border Higher EduCATION}

Given the potential implications for consumer protection, transparency, and the general trustworthiness of European higher education, surprisingly until recently there was very little information about the extent and quality assurance of such cross-border provision of higher education. On behalf of the European Commission (the executive branch of the European Union), CHE Consult has now published the first systematic research and comprehensive overview on branch campuses, franchising, and validation activities in the European Union, as well as a comparative overview of national legislation governing their estab- 
lishment in the European Union. By collecting and verifying data from ministries, quality-assurance agencies, rectors' conferences, CBHE providers, and recognition organizations in all 27 member states, we were able to identify 253 instances of branch campuses, franchising, and validation activities that are currently going on in the European Union. The full report can be accessed under http: / / ec.europa.eu/education/highereducation/doc/studies/borders_en.pdf.

The results confirm earlier research on cross-border higher education. Firstly, Anglophone countries are major providers of higher education services. Second, economically stronger countries serve as "exporters" of degrees, while economically weaker countries tend to be recipients. The study identified Great Britain, the United States, France, and Poland as the main providers of CBHE arrangements in EU member states, whereas Greece, Spain, and Hungary are the main receivers. More interestingly, we were able to demonstrate that the number of such received activities in a country shows a strong statistical relationship to the percentage of its students leaving to study abroad.

\section{LEGISLATION IS OFTEN INCONSISTENT}

Since it is in the exclusive domain of EU member states, legislation on higher education is highly diverse in the European Union: Some member states do not have a policy on CBHE. Of those who do have a policy, it may range from compulsory registration as a means to monitor activities to the outright ban of certain forms of provision. Some member states require proof of accreditation of the exporting country, others require institutions to be authorized by national authorities. In some cases, member states require foreign providers to undergo an additional accreditation, effectively forcing them to become part of the national high- 
er education system, which seems to be a clear violation of the EU Court rulings. Short of outright banning CBHE activity, member states sometimes impede the operations of foreign CBHE providers by denying holders of their degrees access to the national education system; excluding them from access to state-regulated professions or government employment (which might be in contradiction of EU law); while at the same time barring foreign providers from seeking national accreditation. The study contains a detailed description of the various member states' legislation on provider mobility.

\section{LOOPHOLES IN QUALITY ASSURANCE}

Our research also identified inconsistencies and potential loopholes in current European legislation of CBHE activities: On the European level, the European Union strictly enforces the common market and guarantees the recognition of certificates and diplomas in different member states. At the same time, the responsibility for quality assurance lies with the individual member states. Because of highly heterogeneous registration requirements and the absence of a joint register of "white-listed" providers and programs, rogue providers have been known to take advantage of the system. The validation activities of the University of Wales (UK) provide an interesting example of how structural and contin-

gent factors can interact in the CBHE field. The University of Wales was unusual in being a federal institution awarding degrees but not directly running any of its constituent universities. During the 1990s and the 1st decade of the current century, it found itself losing constituent institutions and turned to validation both as a means of securing a role and generating income. By 2009/10 its international 
validation activities were taking place in 140 collaborative centers in 30 countries and accounted for two thirds of its income.

Only in late 2011, after the quality of its validation processes was being put into question of a critical report by the British quality-assurance agency, it was announced that only programs it designed itself and controlled would be available internationally. The fact that the university was able to operate in this way reflects the high level of autonomy in the UK higher education system, the popularity of international activities, the need to generate income and the lack of formal powers of the main quality-assurance body to correct or curtail them. However, within the European Union, no other member state would have had the right to refuse to recognize the University of Wales' degrees.

\section{TOWARD QUALITY ASSURANCE AND TRANSPARENCY}

Our research into the prevalence and regulation of franchising, validation, and branch campuses has made it clear that a converging European higher education area with guaranteed recognition of degrees and freedom of establishment needs corresponding mechanisms of transparency and quality assurance. Such a quality-assurance framework should include a joint European register of recognized, quality-assured higher education institutions and programs. Commonly agreedupon standards and a white list of institutions adhering to them would help to ensure transparency and develop trust in the cross-border education, provided within the European higher education area. 